\title{
The Morphology of the Sphenoid Air Sinus from Childhood to Early Adulthood (1 to 25 years) Utilizing 3D Reconstructed Images
}

\author{
La Morfología del Seno Esfenoidal desde la Infancia hasta la Adultez \\ Temprana (1 a 25 Años) Utilizando Imágenes Reconstruídas en 3D \\ C. Rennie $^{1}$; M.R. Haffajee ${ }^{1} \&$ K. S. Satyapal ${ }^{1}$
}

RENNIE, C.; HAFFAJEE, M. R. \& SATYAPAL, K. S. The morphology of the sphenoid air sinus from childhood to early adulthood (1 to 25 years) utilizing 3D reconstructed images. Int. J. Morphol., 35(4):1261-1269, 2017.

SUMMARY: The morphology of the sphenoid air sinuses is variable amongst populations. The variation in terms of the morphology of this air sinus is particularly important in cranial base surgery. This study aimed to illustrate the three dimensional (3D) morphology of the sphenoid air sinus across ages 1 to 25 years in a South African population. The frequency of the sphenoid sinus characteristics viz. its presence, shape and septa was observed in 3D reconstructed sphenoid sinus models. The sample ( $\mathrm{n}=480$ patients) consisted of 276 males and 204 females, 1-25 years and of two population groups viz. black African and white. The sphenoid air sinus was present in (442/480) $92.1 \%$ on the right and in (441/480) $91.9 \%$ on the left. The sphenoid air sinus was absent in $7.9 \%$ and $8.1 \%$ on the right and left sides respectively. Of those present, six different shapes were identified in the anterior/coronal view. Overall, the main shape identified in the anterior view, was quadrilateral on the right $(n=243 ; 50.6 \%)$ and left $(n=238 ; 49.6 \%)$. There was no association between the shape anteriorly and sex or population groups. However, three forms in the lateral view viz. sellar, presellar and conchal types were documented. The main shape identified was the sellar type on both sides (45.2\% R; $49 \% \mathrm{~L})$. Laterally, there was an association between shape and sex, on the left side only, and, between the population groups ( $\mathrm{p}<0.05)$. Intersinus septa were observed in $90.2 \%$ and located predominantly central in $55.4 \%$. The maximum amount of partial intrasinus septa observed was up to 7 septa. An in depth analysis and classification of the three dimensional form of the sphenoid air sinus according to age 1-25 years was documented in this study. This study proposed a classification of the air sinus utilizing its three dimensional form. The classification illustrated how the air sinus developed within the sphenoid bone and grows into its surrounding parts in both a lateral and posterior direction.

KEY WORDS: Sphenoid air sinus; Development; 3D reconstruction; Shape; Morphology.

\section{INTRODUCTION}

According to Takahashi (1984), the development of the sphenoid air sinus is similar to that of the frontal air sinus, as it develops between two osseous walls. However, according to Levine \& Clemente (2005) its development differs, as it does not appear as an outpouching from the lateral nasal wall, but rather a constriction of the developing presphenoid recess, followed by secondary pneumatization postnatally. Therefore, primary pneumatization does not occur (Levine \& Clemente). At birth the air sinus is nonaerated (Reittner et al., 2001) and the sphenoid bone contains red marrow, which is converted to yellow marrow in the presphenoidal plate between seven months and two years (Scuderi et al., 1993; Reittner et al.). These changes occur before pneumatization can take effect (Scuderi et al.; Reittner et al.). Pneumatization begins before two years of age and sinus maturity may be attained by age fourteen (Scuderi $e t$ $a l$.$) , although some authors indicated a continued growth$ until early adulthood (Wolf et al., 1993; Yonetsu et al., 2000; Reittner et al.; Karakas et al., 2005), and interestingly, thereafter noting that the size decreased after twenty-five years of age (Karakas et al.). Park et al. (2010), noted different phases of development, with a fast phase of growth between six and ten years of age, reaching adult dimensions by fifteen years of age.

Aplasia of the sphenoid sinuses (complete lack of pneumatization) beyond ten years is reported as rare (Scuderi et al.; Orhan et al., 2010; Anusha et al., 2014). The incidence of sphenoid aplasia in the literature was reported as $1-1.5 \%$ in the adult age group (Orhan et al.).

${ }^{1}$ Department of Clinical Anatomy, School of Laboratory Medicine and Medical Sciences, College of Health Sciences, University of KwaZulu-Natal, Westville Campus, Durban, South Africa.

${ }^{2}$ Ethekweni Hospital and Heart Centre, Emergency Medicine Medical Officer and Ex Professor Clinical Anatomy, Durban, South Africa. 
The literature suggests that the degree of pneumatization is often variable (Scuderi et al.), and a highly pneumatized sphenoid sinus may cause anatomical distortion (Anusha $e t$ al.). Still others suggest that a highly pneumatized sphenoid bone, may provide areas of access to the cranial base in surgery (Wang et al., 2010). However, Anusha et al. warned, that surgery in this area should always be done under consideration of the sphenoid air sinus pneumatization, in order to avoid damage of the optic nerve and internal carotid artery.

Few studies have classified the sphenoid air sinus (Wang et al.), however the conventional and widely accepted classification by Hammer and Radberg (1961) is used in most studies. They described sphenoid pneumatization as conchal, presellar and sellar, based on pneumatization around the sella turcica. According to studies conducted, the types of pneumatization may be related to ethnicity, and this could affect surgical outcome i.e. the sellar type as reviewed by Anusha et al. was predominant in Asians. Further to this, Li et al. (2014), stated that the extent of sinus pneumatization may affect the bone covering the carotid arteries and optic, maxillary and vidian nerves making them susceptible to injury.

The air sinus is often described as an asymmetrical pair (Anusha et al.), separated by a septum which commonly deviates to one side (Tan \& Ong, 2007; Anusha et al.). Barghouth et al. (2002) found that this septum may be difficult to visualize in early childhood. According to Anusha et al. population differences occur in terms of the number of septa and its position e.g. in Asians $16.6 \%$ of the septa were found in the midline, with $56.3 \%$ deviated to the left. However, Spaeth et al. (1997), study was conducted in the early stages of CT imaging technology and, the presence of the septum was not evident in their $5600 \mathrm{CT}$ scans.

Only one study analyzed the sphenoid air sinus utilizing three dimensional reconstructed images (Li et al.). In the current study, the author aimed to propose a new classification of the sphenoid air sinus utilizing the shape from three dimensional reconstructed models, classifying the sinus according to age, sex and population groups.

\section{MATERIAL AND METHOD}

Computerized tomography (CT) images of approximately 7000 patients were reviewed from the picture archiving and communication system (PACS) of the state hospital, Greys Hospital, and the archives of radiologists
Jackpersad and Partners, Specialist Diagnostic Radiologists (Ethekweni Hospital and Heart Centre and Isipingo Hospitals) in Pietermaritzburg and Durban KwaZulu- Natal (KZN), South Africa, from patients admitted to the hospitals between 2011-2016 (STATS SA Statistics South Africa, 2016). Ethical clearance was obtained from the University of KwaZulu- Natal Biomedical Research Ethics Committee (BE247/11) and the Department of Health, KZN.

Inclusion Criteria: a) patients between 1-25 years of age b) images without observable signs of abnormal pathological processes of the paranasal air sinuses c) slice thickness $<1.25 \mathrm{~mm} \mathrm{~d}$ ) non- distorted images and e) the largest population groups attending the state and private hospitals above. A final suitable sample $n=480$ patients that satisfied these criteria was obtained. The sample consisted of 276 males and 204 females, all between the ages of 1-25 years old (mean age 14.5 years) and of two population groups (black African and white). The images of each patient were of slice thickness between 0.625 to $1.25 \mathrm{~mm}$ in the axial plane, and were imported to SLICER 3D (3D Slicer, 2012) in order to reconstruct a 3D model of the air sinus. The axial view was selected as the most convenient and easiest method to trace axial contours of the sinuses for further analysis. A 3D model of the sphenoid air sinus bilaterally and unilaterally was reconstructed. Each air sinus 3D model was analyzed to observe the morphology of the sphenoid air sinus. The presence of the air sinus, the number of septa between the right and left sides (intersinus septum) and within the air sinuses (intrasinus septa) were observed. In addition, the shape classification according to Kim et al. (2013), was adapted for the sphenoid air sinus in the anterior (coronal) view, and the lateral (sagittal) view was observed according to Hammer \& Radberg (1961, cited from Wang et al.) classification.

Statistical Analysis. Cross tabulations (to tabulate the frequencies of the parameters) and the Pearson chi square test were adopted in the study utilizing the Statistical Package for social sciences SPSS version 24.0 (IBM® SPSS Inc., Chicago, Illinois, USA). A P-value less than 0.05 was considered statistically significant. The age range of 1-25 years was subdivided into eight three-year categories viz. $1-3 ; 4-6$; 7-9; $10-12 ; 13-15 ; 16-18 ; 19-21 ; 22-25$ to observe the shape of the air sinuses and to compare differences between the variables. The age categories were approximated according to Adibelli et al. (2011) study. The frequency of the morphological parameters was expressed as a count and percentage. The Pearson chi square test was used to show the association between the morphological characteristics and age, sex and population. 


\section{RESULTS}

Presence/Absence of the Sphenoid Air Sinus. In (442/480) $92.1 \%$ the right sphenoid air sinus was present; with $(254 /$ 276) $92 \%$ males, (188/204) $92.2 \%$ females; (396/433) 91.5 $\%$ black African and (46/47), $97.9 \%$ white. The right sphenoid air sinus was absent in 38 cases $(7.9 \%)$. On the left side, the sphenoid air sinus was present in (441/480) $91.9 \%,(256 / 433) 92.8 \%$ males, (185/204) $90.7 \%$ females, (395/433) $91.2 \%$ black African and (49/47) $97.9 \%$ white, with (39/480) $8.1 \%$ absent. There appeared to be consistent symmetry across all variables studied.
The maximum number of absent sphenoid air sinuses from 1 to 3 years was 30 cases $(44.1 \%)$. There was no association between sphenoid aplasia and sex and population groups ( $p>0.05)$, but there was an association with age cohorts $(\mathrm{p}<0.001)$.

\section{Shape of the Sphenoid Air sinus}

a) Anterior View. The sphenoid air sinus was absent in $7.9 \%$ and $8.1 \%$ on the right and left sides respectively. Of the air sinuses present, these were categorised into six different irregular shapes viz. oval, cuboid, triangular, quadrilateral, pentagon, and hexagon. These shapes are illustrated in (Fig.

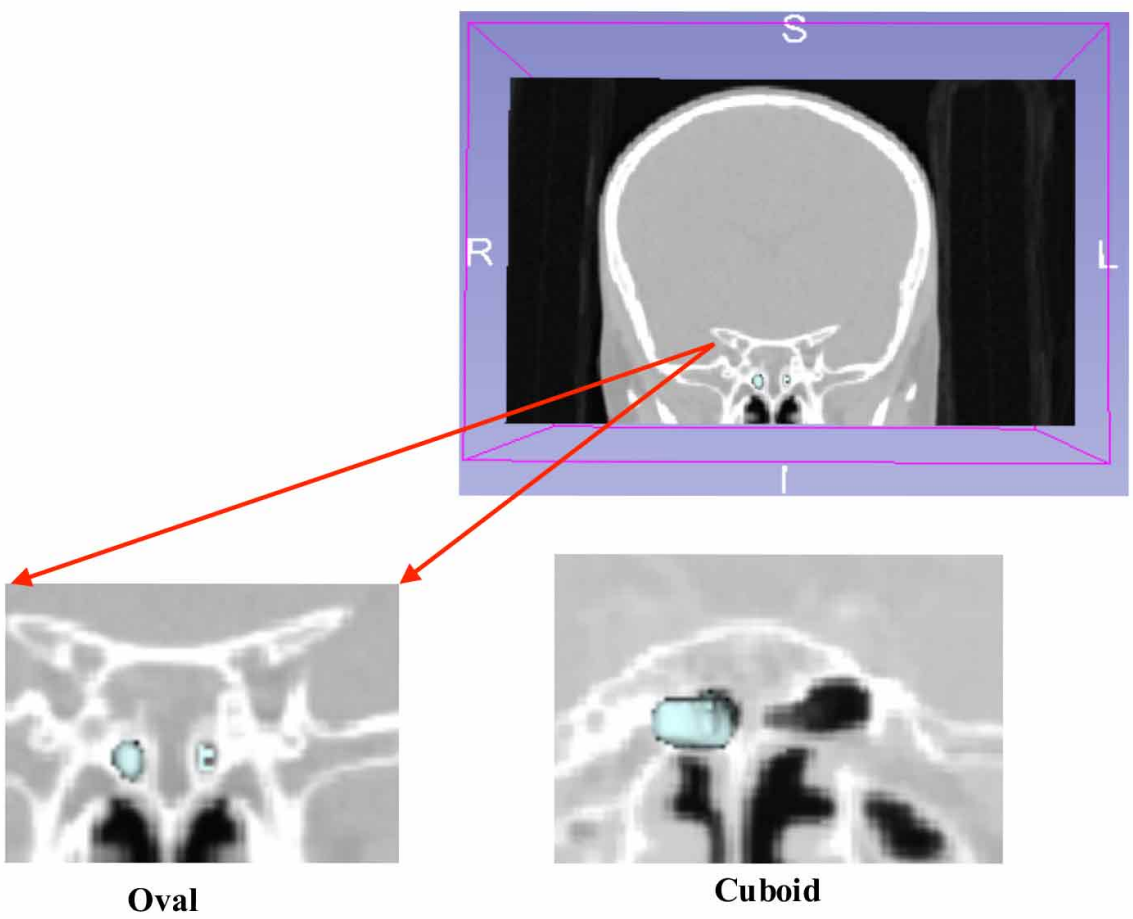

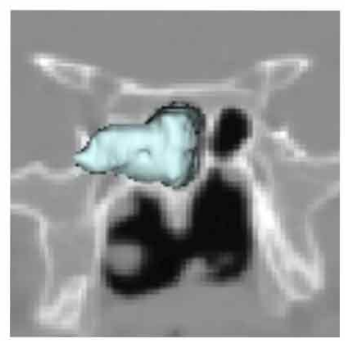

Triangle

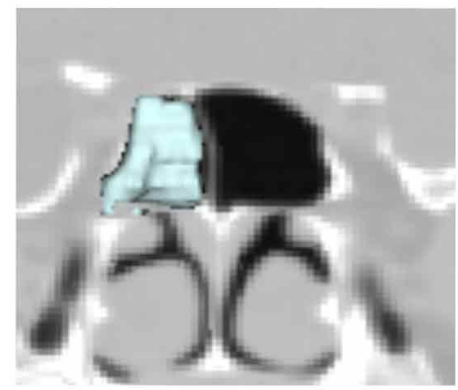

Quadrilateral

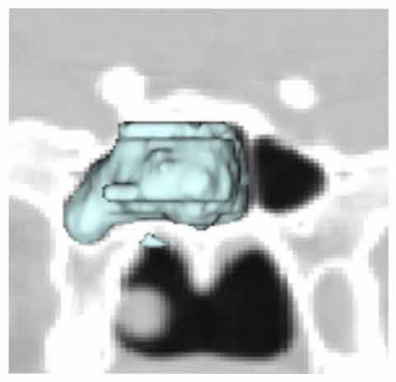

Pentagon

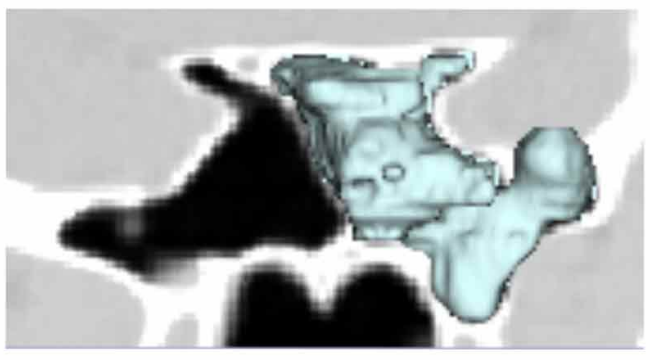

Hexagon

Fig. 1. Classification of the shape of the sphenoid air sinus (Anterior view) 
Table I. Distribution of shape of the Sphenoid air sinus according to sex and population groups (Anterior View).

\begin{tabular}{|c|c|c|c|c|c|c|c|c|}
\hline \multirow[t]{2}{*}{ Description } & \multicolumn{2}{|c|}{ Right side } & \multicolumn{2}{|c|}{ Left side } & \multicolumn{2}{|c|}{ Right side } & \multicolumn{2}{|c|}{ Left side } \\
\hline & $\mathrm{M}$ & $\mathrm{F}$ & $\mathrm{M}$ & $\mathrm{F}$ & BA & W & BA & $\mathrm{W}$ \\
\hline Oval & $15(5.4)$ & $7(3.4)$ & $14(5.1)$ & $7(3.4)$ & $22(5.1)$ & 0 & $21(4.8)$ & 0 \\
\hline Cuboid & $14(5.1)$ & $14(6.9)$ & $13(4.7)$ & $8(4.7)$ & $27(6.2)$ & $1(2.1)$ & $19(4.4)$ & $2(4.3)$ \\
\hline Triangle & $37(13.4)$ & $36(17.6)$ & $35(12.7)$ & $34(16.7)$ & $65(15.0)$ & $8(17.0)$ & $64(14.8)$ & $5(10.6)$ \\
\hline Quadrilateral & $146(52.9)$ & $97(47.5)$ & $147(53.3)$ & $91(44.6)$ & $216(49.9)$ & $27(57.4)$ & $214(49.4)$ & $24(51.1)$ \\
\hline Pentagon & $32(11.6)$ & $27(13.2)$ & $34(12.3)$ & $33(16.2)$ & $51(11.8)$ & $8(17.0)$ & $57(13.2)$ & $10(21.3)$ \\
\hline Hexagon & $10(3.6)$ & $7(3.4)$ & $13(4.7)$ & $11(5.4)$ & $15(3.5)$ & $2(4.3)$ & $19(4.4)$ & $5(10.6)$ \\
\hline p-value & \multicolumn{2}{|c|}{0.679} & \multicolumn{2}{|c|}{0.396} & \multicolumn{2}{|c|}{0.280} & \multicolumn{2}{|c|}{0.102} \\
\hline
\end{tabular}

Shaded area indicates the main shape identified in the cohorts. Key: M- males, F- Females, BA-black African, W-white

Table II. Distribution of shape and site of the sphenoid air sinus according to sex and population groups (Lateral View)

\begin{tabular}{|c|c|c|c|c|c|c|c|c|}
\hline \multirow[t]{2}{*}{ Shape } & \multicolumn{2}{|c|}{ Right } & \multicolumn{2}{|c|}{ Left } & \multicolumn{2}{|c|}{ Right } & \multicolumn{2}{|c|}{ Left } \\
\hline & M & $\mathrm{F}$ & M & $\mathrm{F}$ & BA & W & BA & W \\
\hline Conchal (a) & $25(9.1)$ & $22(10.8)$ & $28(10.1)$ & $19(9.3)$ & $46(10.6)$ & $1(2.1)$ & $46(10.6)$ & $1(2.1)$ \\
\hline Presellar (b) & $105(38.0)$ & $75(36.8)$ & $94(34.1)$ & $65(31.9)$ & $163(37.6)$ & $17(36.2)$ & $147(33.9)$ & $12(25.5)$ \\
\hline Sellar (c) & $125(45.3)$ & $92(45.1)$ & 135 (48.9) & $100(49.1)$ & $189(43.6)$ & $28(59.6)$ & $202(46.7)$ & $33(70.2)$ \\
\hline p-value & \multicolumn{2}{|c|}{0.935} & \multicolumn{2}{|c|}{0.691} & \multicolumn{2}{|c|}{0.057} & \multicolumn{2}{|c|}{0.011} \\
\hline
\end{tabular}

Table IIIa. Distribution of intrasinus septa of the sphenoid air sinus (sex and population groups).

\begin{tabular}{|c|c|c|c|c|c|c|c|c|}
\hline \multirow{2}{*}{$\begin{array}{l}\text { Number of } \\
\text { septa }\end{array}$} & \multicolumn{2}{|c|}{ Male } & \multicolumn{2}{|c|}{ Female } & \multicolumn{2}{|c|}{ Black African } & \multicolumn{2}{|c|}{ White } \\
\hline & $\mathrm{R}$ & $\mathrm{L}$ & $\mathrm{R}$ & $\mathrm{L}$ & $\mathrm{R}$ & $\mathrm{L}$ & $\mathrm{R}$ & $\mathrm{L}$ \\
\hline 0 septa & $116(46.0)$ & $114(45.2)$ & $98(52.7)$ & $81(43.8)$ & $201(51.3)$ & $184(47.1)$ & $13(28.3)$ & $11(23.9)$ \\
\hline 1 septum & $57(22.6)$ & $61(24.2)$ & $30(16.1)$ & $45(24.3)$ & $76(19.4)$ & $97(24.8)$ & $11(23.9)$ & 9 (19.6) \\
\hline 2 septa & $42(16.7)$ & $50(19.8)$ & $41(22.0)$ & $38(20.5)$ & $72(18.4)$ & 77 (19.7) & $11(23.9)$ & $11(23.9)$ \\
\hline 3 septa & $24(9.5)$ & $16(6.3)$ & $13(7.0)$ & $15(8.1)$ & $30(7.7)$ & $21(5.4)$ & $7(23.9)$ & $10(21.7)$ \\
\hline 4 septa & $9(3.6)$ & $9(3.6)$ & $3(1.6)$ & $2(1.1)$ & $11(2.8)$ & $9(2.3)$ & $1(2.2)$ & $2(4.3)$ \\
\hline 5 septa & $3(1.2)$ & $1(0.4)$ & $1(0.5)$ & $2(1.1)$ & $2(0.5)$ & $1(0.3)$ & $2(4.3)$ & $2(4.3)$ \\
\hline 6 septa & $1(0.4)$ & $1(0.4)$ & 0 & $1(0.5)$ & 0 & $2(0.5)$ & $1(2.2)$ & 0 \\
\hline 7 septa & 0 & 0 & 0 & $1(0.5)$ & 0 & 0 & 0 & $1(2.2)$ \\
\hline
\end{tabular}

Table IIIb. Distribution of intrasinus septa of the sphenoid air sinus (age cohorts).

\begin{tabular}{|c|c|c|c|c|c|c|c|c|c|c|c|c|c|c|c|c|}
\hline \multirow{2}{*}{$\begin{array}{l}\text { Age } \\
(\mathrm{yrs})\end{array}$} & \multicolumn{2}{|c|}{0 septa } & \multicolumn{2}{|c|}{1 septum } & \multicolumn{2}{|c|}{2 septa } & \multicolumn{2}{|c|}{3 septa } & \multicolumn{2}{|c|}{4 septa } & \multicolumn{2}{|c|}{5 septa } & \multicolumn{2}{|c|}{6 septa } & \multicolumn{2}{|c|}{7 septa } \\
\hline & $\mathrm{R}$ & $\mathrm{L}$ & $\mathrm{R}$ & $\mathrm{L}$ & $\mathrm{R}$ & $\mathrm{L}$ & $\mathrm{R}$ & $\mathrm{L}$ & $\mathrm{R}$ & L & $\mathrm{R}$ & $\mathrm{L}$ & $\mathrm{R}$ & $\mathrm{L}$ & $\mathrm{R}$ & $\mathrm{L}$ \\
\hline $1-3$ & 36 & 35 & 0 & 0 & 0 & 1 & 0 & 0 & 0 & 0 & 0 & 0 & 0 & 0 & 0 & 0 \\
\hline $4-6$ & 28 & 29 & 10 & 6 & 2 & 3 & 0 & 0 & 0 & 0 & 0 & 0 & 0 & 0 & 0 & 0 \\
\hline $7-9$ & 22 & 19 & 5 & 6 & 2 & 3 & 0 & 1 & 0 & 0 & 0 & 0 & 0 & 0 & 0 & 0 \\
\hline $10-12$ & 18 & 17 & 8 & 11 & 6 & 7 & 4 & 2 & 1 & 1 & 1 & 0 & 1 & 1 & 0 & 0 \\
\hline $13-15$ & 18 & 17 & 6 & 7 & 16 & 12 & 3 & 3 & 0 & 3 & 0 & 0 & 0 & 0 & 0 & 1 \\
\hline $16-18$ & 19 & 20 & 19 & 17 & 12 & 13 & 4 & 4 & 1 & 2 & 1 & 0 & 0 & 0 & 0 & 0 \\
\hline $19-21$ & 33 & 26 & 16 & 28 & 23 & 21 & 10 & 10 & 6 & 2 & 0 & 2 & 1 & 0 & 0 & 0 \\
\hline $22-25$ & 40 & 32 & 23 & 31 & 22 & 28 & 16 & 11 & 4 & 3 & 2 & 1 & 0 & 1 & 0 & 1 \\
\hline
\end{tabular}

1). Overall, the main shape identified was quadrilateral on the right $(\mathrm{n}=243 ; 50.6 \%)$ and left $(\mathrm{n}=238 ; 49.6 \%)$. Table I illustrated that the main shape identified in males was quadrilateral $(\mathrm{n}=146 ; 52.9 \%)$ on the right, and on the left $(\mathrm{n}=147 ; 53.3 \%)$. A quadrilateral shape was identified as the main type in females $(n=97 ; 47.5 \%)$ on the right and on the left $(n=91 ; 44.6 \%)$. This shape was dominant in Black African and white populations as follows: black African $(\mathrm{n}=216 ; 49.9 \%)(\mathrm{R}) ;(\mathrm{n}=214 ; 49.4 \%)(\mathrm{L})$, whilst, $(\mathrm{n}=27$; $57.4 \%)(\mathrm{R}),(\mathrm{n}=24 ; 51.1 \%)(\mathrm{L})$ in the white population group. There was no association found in terms of the shape anteriorly, with sex or population groups ( $\mathrm{p}>0.05)$. 

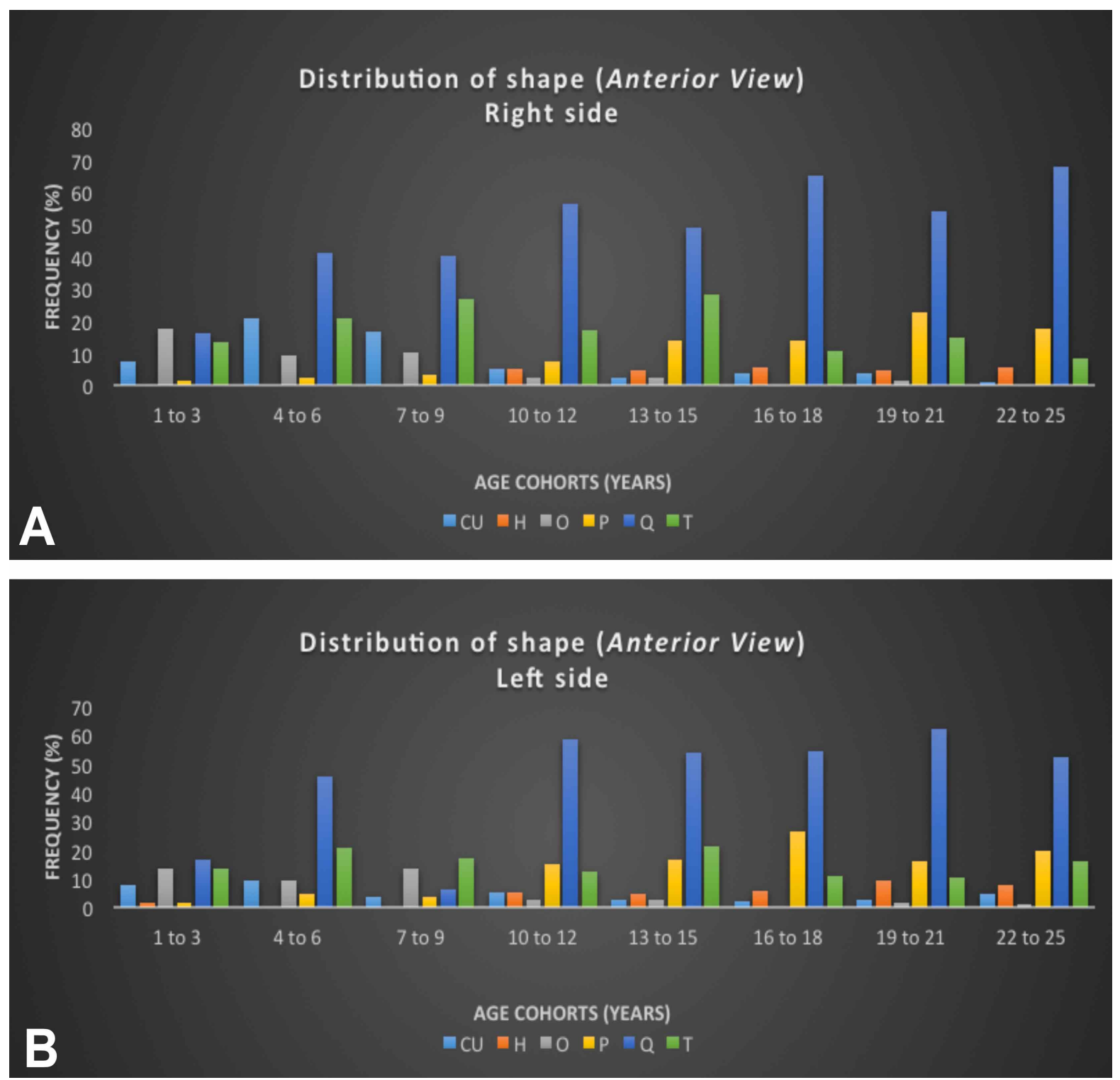

Fig. 2. A and B. Graph illustrating shape of the sphenoid air sinus according to age (Anterior view). Key: CU-cuboid, O-oval, T- triangle, Q- quadrilateral, $\mathrm{P}$ - pentagon, H-hexagon

A shape could be identified during each age cohort from the air sinuses that was present. On the right and left sides, the main shape identified was quadrilateral. There was an association between the age cohorts and shapes anteriorly $(p<0.001)$. In the anterior view, it would appear that the shape illustrated the lateral extension of the air sinus. The forms of oval to irregular six sided shapes illustrated its progression within the sphenoid and surrounding bones (Figs. 2a and b).

b) Lateral View. Three shapes in the lateral view were observed viz. conchal, presellar and sellar (Table II, Figs. $3 \mathrm{a}, \mathrm{b}, \mathrm{c}$.) It was noted that the main shape identified on both sides ( $\mathrm{n}=217,45.2 \% \mathrm{R} ; \mathrm{n}=235,49 \% \mathrm{~L})$ and in both male $(\mathrm{n}=125,45.3 \% \mathrm{R} ; \mathrm{n}=135,48.9 \% \mathrm{~L})$ and female $(\mathrm{n}=92$, $45.1 \% \mathrm{R} ; \mathrm{n}=100,49 \% \mathrm{~L}$ ) was the sellar type. According to the population groups, the main shape observed was sellar in both groups [black African $(n=189,43.6 \% \mathrm{R} ; \mathrm{n}=202$, $46.7 \% \mathrm{~L})$ and white $(\mathrm{n}=28 ; 59.6 \% \mathrm{R} ; \mathrm{n}=33,70.2 \% \mathrm{~L})$. Laterally, there was an association between shape laterally and the population groups on the left side only $(\mathrm{p}=0.011)$. Laterally on both sides, the shape appeared to be sellar mainly after 10 to 12 years, whilst the conchal type decreased with age and was not evident from 16 to 18 years of age. The presellar type was present throughout the age cohort (Figs. $4 \mathrm{a}$ and $\mathrm{b}$ ). There was an association between age and shape $(\mathrm{p}<0.001)$. 
c) Septa. Intrasinus septa did not completely divide the sphenoid air sinus and was contained within the chamber. The highest amount of intrasinus septa observed was up to seven septa in one case, on the left side in a white female. Most of the sample had no intrasinus septa ( $44.6 \%$ R: $40.67 \%$ L). This distribution of septa is observed in Table III $a$ and $b$.
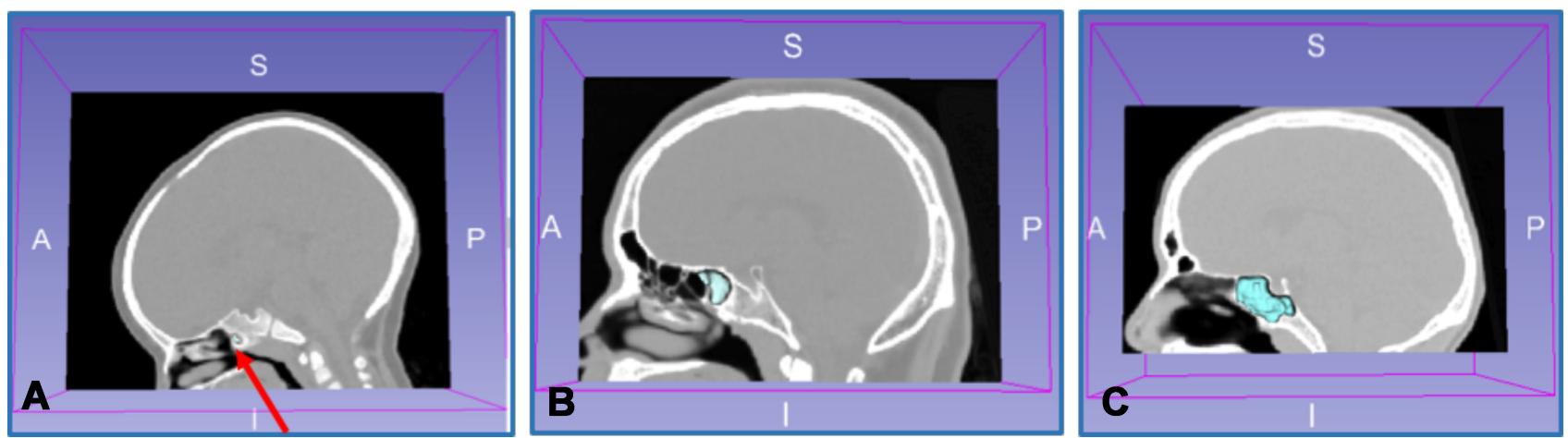

Fig. 3 a, b, c: Lateral view of sphenoid air sinus.
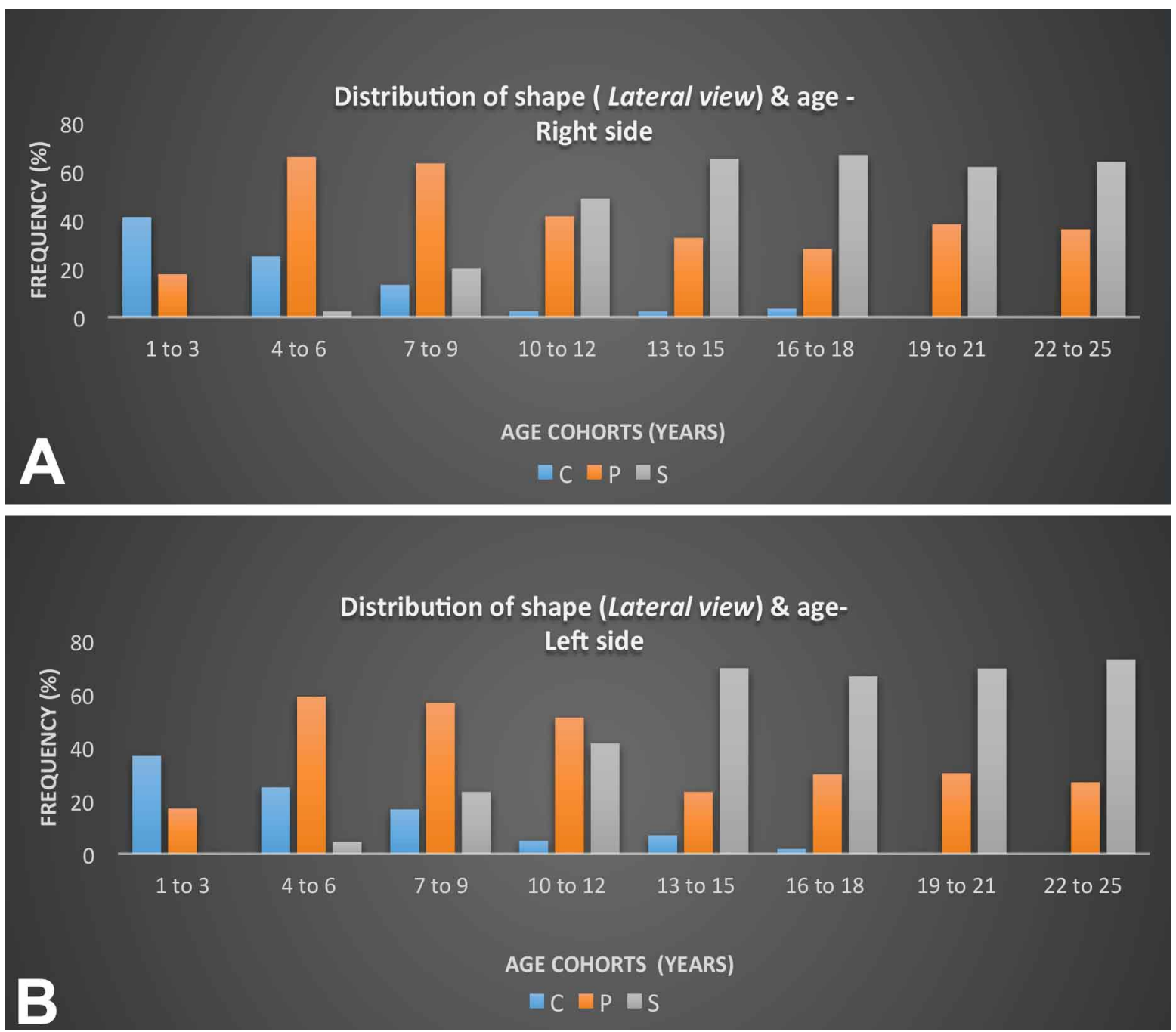

Fig. 4. a and b. Graph illustrating shape of the sphenoid air sinus according to age (Lateral view) Key: C-conchal, P-presellar, S-sellar 
Table IV. Distribution of Intersinus septa of the sphenoid air sinus.

\begin{tabular}{lccc}
\hline & Right & Central & Left \\
\cline { 2 - 4 } & $\mathrm{N}(\%)$ & $\mathrm{N}(\%)$ & $\mathrm{N}(\%)$ \\
\hline Male & 45 & $154(55.8)$ & $53(19.2)$ \\
Female & $43(21.1)$ & $112(54.9)$ & $26(12.7)$ \\
Black & $75(17.3)$ & $240(55.4)$ & $72(16.6)$ \\
White & $13(27.7)$ & $26(55.3)$ & $7(14.9)$ \\
$1-3$ & $1(1.5)$ & $31(45.6)$ & $0(0)$ \\
$4-6$ & $4(9.1)$ & $32(72.7)$ & $2(4.5)$ \\
$7-9$ & $4(13.3)$ & $24(80)$ & $1(3.3)$ \\
$10-12$ & $9(22.0)$ & $21(51.2)$ & $8(19.5)$ \\
$13-15$ & $9(30.2)$ & $21(48.8)$ & $13(20.9)$ \\
$16-18$ & $14(15.8)$ & $33(57.9)$ & $9(24.6)$ \\
$19-21$ & $21(27.0)$ & $44(49.4)$ & $24(23.6)$ \\
$22-25$ & $24(22.2)$ & $60(55.6)$ & $22(22.2)$ \\
\hline
\end{tabular}

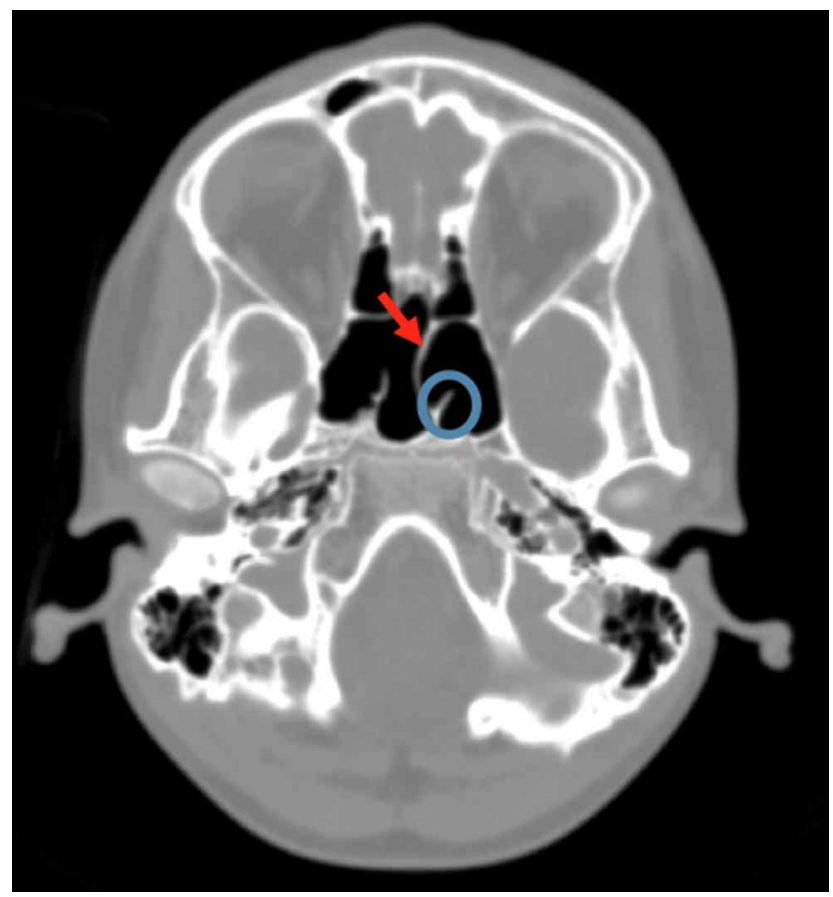

Fig. 5. Intrasinus septa (blue circle), and intersinus septa (red arrow).

\section{DISCUSSION}

Li et al. is the only other study that has illustrated the air sinus in three dimensions. The current study illustrated the 3D form of the sphenoid air sinus illustrating its form according to age, sex and population groups. It is apparent after an extensive literature review that there are no reports with respect to this. In the current study, the sphenoid air sinus was present in $92.1 \%$ and $91.9 \%$ of the sample, on the right and left sides respectively. The air sinus was absent in $7.9 \%$ right and $8.1 \%$ left. Most of the absence occurred in the first three years. This is consistent with the development of the air sinus. At birth, the air sinus is nonaerated (Reittner et al.) and the sphenoid bone contains red marrow, which is converted to yellow marrow in the presphenoidal plate between seven months and two years (Scuderi et al.; Reittner et al.). These changes occur before pneumatization takes place. Pneumatization is delayed and begins after two years of age (Scuderi et al.) or three years of age (Duque \& Casiano, 2005). These changes may explain the current study findings. In addition, aplasia present beyond ten to twelve years in this study was in $0.2 \%$ of the total sample. This is consistent with the literature which reported $1-1.5 \%$ in the adult age group (Orhan et al.).

a) Shape and Age. Most studies classified the air sinus according to Hammer \& Radburg (1961, cited by Wang et $a l$.). This classification illustrated the air sinus' site in relation to the sella turcia as either conchal, presellar and sellar types. The growth of the air sinus in a posterior and downward direction in relation to the sella region was described. In the current study, the air sinus was classified by looking at the structure and site in three dimensions in relation to the surrounding bone. In the anterior/coronal view, the air sinus was found to have six different forms that were irregular viz. oval, cuboid, triangular, quadrilateral, pentagon and hexagon. These forms seem to illustrate the extension of the air sinus in the lateral direction. The most prominent shape was quadrilateral followed by the pentagon on the right and triangular form on the left side. The 3D models were irregular shapes with either four or five sides. The rounded or cuboidal shapes were found mainly between 1 to 3 years of age. In the late$\mathrm{ral} / \mathrm{sagittal}$ view, the air sinus was conchal, presellar and sellar types. These findings indicated that the conchal form is mainly observed from 1 to ten years of age, followed by the adult form- sellar type. In addition, it was observed that the sellar type was a dominant form observed in the South African population, consistent with other studies such as Orhan et al.

The dominant shapes in the anterior and lateral view may provide some insight into the progression of pneumatization of the sphenoid bone. The findings suggest that pneumatization begins as a circular structure that is confined to the sphenoid bone in the area of the sphenoethmoidal recess anteriorly. As pneumatization progresses it is contained within the body of the sphenoid bone as suggested by the quadrilateral form. The air sinus then progresses rapidly in an inferior direction with this sellar form dominant from 10 to 12 years that can be viewed laterally. This may suggest that the air sinus may attain its adult form by 10 to 12 years of age, as confirmed by Reittner et al. 
This study also illustrated that the shape is significantly different according to age. There are limited studies that have assessed the 3D form of the air sinus from one to twenty five years of age. Most have illustrated pneumatization in an adult sample, and hence the conchal form may not be seen in their studies (Idowu et al., 2009), although the conchal form may be present in $2.5 \%$ of the adults as suggested by Orhan et al. In the current study, the conchal form was observed in $9.8 \%$ on the right and left sides of the sample. This mainly occurred in the 1 to 3 year age category. These findings are important as explained by Orhan et al., as the conchal form and aplasia may make trans nasal surgery difficult.

In addition, the pentagon shape illustrated in (12.3 $\% \mathrm{R}, 14.0 \% \mathrm{~L}$ ) of the sample, suggests that pneumatization may extend into the greater wings of the sphenoid, with hexagon types $(3.5 \% \mathrm{R}, 5.0 \% \mathrm{~L})$ pneumatizing the greater wing and pterygoid plate of the sphenoid bone (Fig. 1a-f). Further study is necessary to illustrate the relationship of the surrounding neurovascular structures to these various types observed in three dimensions.

b) Sex and Population. The main shape identified between the population groups and between male and female was a quadrilateral form in the anterior view. In the lateral view, it was noted that the main shape identified on both sides $(\mathrm{n}=217,45.2 \% \mathrm{R} ; \mathrm{n}=235,49 \% \mathrm{~L})$ and in both male $(\mathrm{n}=125$, $45.3 \% \mathrm{R} ; \mathrm{n}=135,48.9 \% \mathrm{~L})$ and female $(\mathrm{n}=92,45.1 \% \mathrm{R}$; $\mathrm{n}=100,49 \% \mathrm{~L}$ ) was the sellar type. According to the population groups, the main shape observed was sellar in both groups [black African ( $\mathrm{n}=189,43.6 \% \mathrm{R} ; \mathrm{n}=202,46.7$ $\% \mathrm{~L})$ and white $(\mathrm{n}=28 ; 59.6 \% \mathrm{R} ; \mathrm{n}=33,70.2 \% \mathrm{~L})$.

Anteriorly and laterally, there was no association between the shape and sex, but an association was found between shape and population groups on the left side only, $(\mathrm{p}=0.011)$. Very few studies have illustrated sexual dimorphism of the air sinus. Most studies illustrated that the sellar form is dominant in populations (Anusha et al.).

Other morphological traits. The intersinus septum divided the sphenoid air sinus completely. It was observed in most of the sample $(\mathrm{n}=433 ; 90.2 \%)$ and was either central $(\mathrm{n}=266$; $55.4 \%)$, towards the right side $(\mathrm{n}=88 ; 18.3 \%)$ or more towards the left side $(\mathrm{n}=79 ; 16.5 \%)$.In this study, the intersinus was mainly centrally located and differed from previous studies, which indicated that it either deviated more to the left or right (Anusha et al.). Intrasinus septa did not completely divide the sphenoid air sinus and was contained within the chamber (Tan \& Ong, 2007). Most of the sample of the current study had no intrasinus septa ( $44.6 \% \mathrm{R}: 40.67 \% \mathrm{~L}$ ). This may be due to the current study sample consisting of a large paediatric group.

\section{CONCLUSION}

This study highlighted the variable 3D forms of the sphenoid air sinus according to age, sex and population groups. An in- depth study of the 3D morphological variation according to age was established. The age related changes and classification according to form provided some insight into the development of the sphenoid air sinus particularly in the lateral direction within the parts of the sphenoid bone. Laterally, the air sinus is related to a number of important structures viz. the internal carotid artery, branches of the trigeminal nerve and optic nerves. Further research will be necessary to illustrate the three dimensional forms of the air sinus identified in this study in relation to these neurovascular structures.

RENNIE, C.; HAFFAJEE, M. R. \& SATYAPAL, K. S. La morfología del seno esfenoidal desde la infancia hasta la adultez temprana utilizando imágenes reconstruídas en 3D. Int. J. Morphol., 35(4):1261-1269, 2017.

RESUMEN: La morfología de los senos esfenoides puede variar entre las poblaciones. La variación en términos de morfología de este seno es particularmente importante en la cirugía de base de cráneo. Este estudio tuvo como objetivo ilustrar la morfología tridimensional (3D) del seno esfenoidal en una población sudafricana entre las edades de 1 a 25 años. La frecuencia de las características de los senos esfenoides, su presencia, forma y septo se observó en los modelos de seno esfenoidal, reconstruido en tres dimensiones. La muestra ( $n=480$ pacientes $)$ consistió en 276 varones y 204 mujeres, 1-25 años, divididos en dos grupos de población africana negra y blanca. El seno esfenoidal estaba presente en 92,1\% (442/ 480 ) en el lado derecho, y en $91,9 \%$ (441/480) en el lado izquierdo. El seno esfenoidal estaba ausente en $7,9 \%$ y $8,1 \%$, en los lados derecho e izquierdo, respectivamente. Se identificaron seis formas diferentes en la vista anterior / coronal. En general, la forma principal identificada en la vista anterior fue cuadrilátero: 50,6\% a la derecha $(n=243)$, y 49,6\% a la izquierda $(n=238)$. No hubo asociación entre la forma anterior y el sexo, o en grupos de población. Sin embargo, se observaron en la imagen lateral tres tipos, que fueron documentados: sellar, presellar y conchal. La forma principal identificada fue el tipo sellar en ambos lados (45,2 \% derecha, $49 \%$ izquierda). Lateralmente, se presenta una asociación entre la forma y los sexos, sólo en el lado izquierdo, y entre los grupos de población ( $\mathrm{p}<0,05)$. Se observaron septos interinos en el 90,2 \%; de éstos, un $55,4 \%$ se presentaban de forma centralizada. La cantidad máxima de septos parciales interinos fue de hasta 7 . En este estudio se documentó un análisis en profundidad y clasificación de la forma tridimensional del seno esfenoidal según la edad, de 1 a 25 años. Este estudio propuso una clasificación del seno esfenoidal utilizando su forma tridimensional. La clasificación presentó el desarrollo del seno esfenoidal dentro del hueso esfenoides y el crecimiento en sus partes circundantes, tanto en dirección lateral como posterior.

PALABRAS CLAVE: Seno esfenoidal; Desarrollo; Reconstrucción 3D; Forma; Morfología. 


\section{REFERENCES}

3D Slicer, 2012. Available from: www.slicer.org

Adibelli, Z. H.; Songu, M. \& Adibelli, H. Paranasal sinus development in children: A magnetic resonance imaging analysis. Am. J. Rhinol. Allergy, 25(1):30-5, 2011.

Anusha, B.; Baharudin, A.; Philip, R.; Harvinder, S. \& Shaffie, B. M. Anatomical variations of the sphenoid sinus and its adjacent structures: a review of existing literature. Surg. Radiol. Anat., 36(5):419-27, 2014.

Barghouth, G.; Prior, J. O.; Lepori, D.; Duvoisin, B.; Schnyder, P. \& Gudinchet, F. Paranasal sinuses in children: size evaluation of maxillary, sphenoid, and frontal sinuses by magnetic resonance imaging and proposal of volume index percentile curves. Eur. Radiol., 12(6):14518, 2002.

Duque, C. S. \& Casiano, R. R. Surgical Anatomy and Embryology of the Frontal Sinus. In: Kountakis, S. E.; Senior, B. A. \& Draf, W. (Eds). The Frontal Sinus. Heidelberg, Springer, 2005. pp.21-31.

Idowu, O. E.; Balogun, B. O. \& Okoli, C. A. Dimensions, septation, and pattern of pneumatization of the sphenoidal sinus. Folia Morphol. (Warsz.), 68(4):228-32, 2009.

Karakas, S. \& Kavakli, A. Morphometric examination of the paranasal sinuses and mastoid air cells using computed tomography. Ann. Saudi Med., 25(1):41-5, 2005.

Kim, D. I.; Lee, U. Y.; Park, S. O.; Kwak, D. S. \& Han, S. H. Identification using frontal sinus by three-dimensional reconstruction from computed tomography. J. Forensic Sci., 58(1):5-12, 2013.

Levine, H. L. \& Clemente, M. P. Surgical Anatomy of the Paranasal Sinus. In: Levine, H. L. \& Clemente, M. P. (Eds.). Sinus Surgery: Endoscopic and Microscopic Approaches. New York, Thieme, 2005.

Li, Y.; Sun, J.; Zhu, X.; Zhao, C.; Xu, J.; Jiang, P. \& Tong, X. Study of the relationship between sphenoid sinus volume and protrusions in the sphenoid sinus. FMAR, 2(1):2-7, 2014.

Orhan, M.; Govsa, F. \& Saylam, C. A quite rare condition: absence of sphenoidal sinuses. Surg. Radiol. Anat., 32(6):551-3, 2010.

Park, I. H.; Song, J. S.; Choi, H.; Kim, T. H.; Hoon, S.; Lee, S. H. \& Lee, H. M. Volumetric study in the development of paranasal sinuses by CT imaging in Asian: a pilot study. Int. J. Pediatr. Otorhinolaryngol., 74(12):1347-50, 2010.

Reittner, P.; Doerfler, O.; Goritschnig, T.; Tillich, M.; Koele, W.; Stammberger, H. \& Szolar, D. H. Magnetic resonance imaging patterns of the development of the sphenoid sinus: a review of 800 patients. Rhinology, 39(3):121-4, 2001.

Scuderi, A. J.; Harnsberger, H. R. \& Boyer, R. S. Pneumatization of the paranasal sinuses: normal features of importance to the accurate interpretation of CT scans and MR images. A. J. R. Am. J. Roentgenol., 160(5):1101-4, 1993.

Spaeth, J.; Krügelstein, U. \& Schlöndorff, G. The paranasal sinuses in CTimaging: development from birth to age 25. Int. J. Pediatr. Otorhinolaryngol., 39(1):25-40, 1997.

STAT S Statistics South Africa, 2016. Available from: www.statssa.gov.za

Takahashi, R. The formation of the human paranasal sinuses. Acta Otolaryngol. Suppl., 408:1-28, 1984.

Tan, H. K. \& Ong, Y. K. Sphenoid sinus: an anatomic and endoscopic study in Asian cadavers. Clin. Anat., 20(7):745-50, 2007.

Wang, J.; Bidari, S.; Inoue, K.; Yang, H. \& Rhoton, A. Jr. Extensions of the sphenoid sinus: a new classification. Neurosurgery, 66(4):797-816, 2010.

Wolf, G.; Anderhuber, W. \& Kuhn, F. Development of the paranasal sinuses in children: implications for paranasal sinus surgery. Ann. Otol. Rhinol. Laryngol., 102(9):705-11, 1993.

Yonetsu, K.; Watanabe, M. \& Nakamura, T. Age-related expansion and reduction in aeration of the sphenoid sinus: volume assessment by helical CT scanning. A. J. N. R. Am. J. Neuroradiol., 21(1):179-82, 2000.

\author{
Corresponding author: \\ Professor KS Satyapal \\ Department of Clinical Anatomy \\ School of Laboratory Medicine and Medical Sciences \\ College of Health Sciences \\ University of KwaZulu-Natal \\ Private Bag X54001 \\ Durban 4000 \\ SOUTH AFRICA
}

E-mail : satyapalk@ukzn.ac.za

Received: 05-02-2017

Accepted: 19-07-2017 